\title{
B3GAT1 wt Allele
}

National Cancer Institute

\section{Source}

National Cancer Institute. B3GAT1 wt Allele. NCI Thesaurus. Code C101764.

Human B3GAT 1 wild-type allele is located in the vicinity of 11 q25 and is approximately 33 $\mathrm{kb}$ in length. This allele, which encodes galactosylgalactosylxylosylprotein 3-betaglucuronosyltransferase 1 protein, is involved in the addition of carbohydrate to proteins. 